\title{
Liter per Gram per Second
}

National Cancer Institute

\section{Source}

National Cancer Institute. Liter per Gram per Second. NCI Thesaurus. Code C85660.

Liters per gram per second. 